\title{
AN INTEGRATIVE APPROACH TO HRM -FIRM PERFORMANCE RELATIONSHIP: A MISSING LINK TO CORPORATE GOVERNANCE
}

\author{
Jelena Petrovic (corresponding author) \\ Associate Professor of Strategic Leadership \\ Kingston University, Business School \\ J.Petrovic@kingston.ac.uk
}

\author{
George Saridakis \\ Professor of Small Business and Entrepreneurship \\ Kent University, Business School \\ G.Saridakis@kent.ac.uk
}

\begin{abstract}
Stewart Johnstone
Senior Lecturer in HRM and Employment Relations

Newcastle University, Business School

stewart.johnstone@ncl.ac.uk
\end{abstract}




\begin{abstract}
Purpose

The purpose of this paper is to contribute to ongoing debates regarding the human resource management (HRM)-firm performance relationship. In seeking to provide a more complete picture of the relationship, the paper discusses the existing literature and proposes an integrative framework that draws upon different literatures and multiple theoretical perspectives.

\section{Design/methodology/approach}

Our review includes nearly 100 research studies published in this field. The review includes articles published in mainstream HRM journals and broader management journals with strong ties to HRM literature. Importantly, the paper also identifies a gap - a missing link - that concerns the importance of incorporating insights from corporate governance literature when considering strategic HR decision making.
\end{abstract}

\title{
Findings
}

A significant contribution of this paper to theory is to propose an integrative framework that conceptualises the elusive relationship between HRM and firm performance, and which draws on different literatures and multiple theoretical perspectives in to offer more holistic insights into the relationship. The paper discusses the implications of the integrative perspective for theory and practice.

\section{Originality/value}

This paper argues that one of the main stumbling blocks for developing a better understanding of the mechanisms through which HRM creates value in an organisation is the fragmentation of the HRM literature between "HR as practices" versus "HR as the department/profession", as well as a tendency to neglect insights from the corporate governance literature.

Key words: HRM, Firm Performance, Corporate Governance. 


\section{Introduction}

A shareholder perspective has traditionally been used to measure firm performance, using financial performance indicators such as return on investment, financial and market performance, and productivity (Becker and Gerhart, 1996). This is not surprising given that the primacy of shareholder concerns (in the Anglo/Saxon corporate governance system at least) means that for boards charged with satisfying interests of shareholders, the ultimate human resource management (HRM) - firm performance related question would be, how does a particular change in HRM affect shareholder returns? The main HRM issue from this perspective can therefore be summed up as a question of costs versus contribution/value creation.

There is a general agreement in the literature that HRM has the potential to affect firm performance through its influence on employee behaviour (Combs et al., 2006; Beer, 2015; Chadwick et al., 2015; Cappelli, 2015). However, there is very little agreement regarding how to achieve this potential because of various methodological and conceptual limitations. These include a lack of consensus regarding how to best operationalise HRM and firm performance, a tendency to examine different HR practices as well as to use different measures, and to report associations rather than causation. Studies are also inconsistent in how they define the concept of firm performance, and are questionable in terms of their cross-national generalisability (Wall and Wood, 2005; Guest, 2011; Paauwe et al., 2012; Brewster et al., 2016).

There is also further evidence that suggests executives fail to see tangible associations between the role of the HR department and firm performance (Charan et al., 2015). Creating models that reflect a broader view of performance and more complete taxonomies of factors influencing business and HR strategies remains a challenge (Cascio, 2015). Becker and Gerhart (1996) noted over 20 years ago when empirical HR-performance research was in its infancy, that the mechanisms through which HR decisions create and sustain value are complicated and not 
well understood. Some two decades and many empirical studies later, Guest (2011, p.3) suggests that "we are more knowledgeable but not much wiser, in that we have not been able to explain the demonstrated association between HRM and performance with any conviction”.

With some exceptions (e.g., Welbourne and Cyr, 1999; Hope Hailey et al., 2005; Singh et al., 2012; Martin and Gollan, 2012; Sheehan et al., 2014; Chadwick et al., 2016), most studies of the so-called "black box" of the HRM - performance relationship focus upon HR practices (processes/systems/policies/strategies), rather than the role played by the HR department in making strategic HR decisions. On the other hand, the stream of research that focuses on the influence of HR department/professionals on strategic decision making on the board (e.g., Ulrich and Brockbank, 2005; Kelly and Gennard, 2007; Charan et al., 2015) tends to exclude a more indepth consideration of HR practices and their relationship to firm performance. Moreover, while one would expect this stream of literature to be complemented by research in the field of corporate governance (top management teams / board directors) this does not tend to be the case.

Considering a significant body of existing literature, this paper argues that one of the main stumbling blocks for developing a better understanding of the mechanisms through which HRM creates value in an organisation, is the fragmentation of the literature between studies of $H R$ practices with those that explore the role of the HR department/profession, as well as a tendency to neglect insights from the corporate governance literature. Given the vast literature on HRMperformance, to make the task manageable and for reasons of brevity, the studies included in this review are necessarily selective rather than exhaustive. Nevertheless, we believe they allow for an overview of the recent trajectory of research on HRM and performance. In seeking to provide a more complete picture of the HRM - firm performance relationship, this paper proposes a framework that integrates these different streams of the HRM literature (HR as practices versus $\mathrm{HR}$ as the department/profession) as well as insights from the corporate governance literature. In 
doing so, the paper draws on multiple theoretical perspectives in order to develop a more holistic understanding of the HRM-performance link. The need for an integrative review of the literature has been highlighted by various scholars (e.g., Guest, 2011; Wright et al., 2014). Indeed, as suggested by Wright et al. (2014), who used the story of blind men and the elephant to illustrate that no one's subjective experience completely describes a phenomenon, "if all the blind men were to communicate with one another about the part they describe, their pooled descriptions would closely resemble the elephant" (p.368).

The paper is structured as follows. The first section discusses key published work that concentrates on HR practices and the relationship with firm performance. This stream of literature has been divided into two sub-areas, each seen through a different theoretical lens: designing HR practices (the resource based view -RBV- of the firm) and implementing HR practices (the resource orchestration perspective). The section that follows discusses the literature about the role of HR department/professionals in influencing strategic decision making on the board. The next section then considers issues of HR metrics (workforce/analytics) and firm performance, as these concern both HR practices and the role of HR department/professionals. The following section then proposes a missing link to corporate governance and discusses some key issues pertinent to strategic leadership role of top management team (TMT) and board members and their implications for $\mathrm{HR} .{ }^{1} \mathrm{We}$ then present an integrative framework that conceptualises how the relationship between HRM and firm performance works, drawing on different literatures and multiple theoretical perspectives and explaining the implications for both theory and practice. The final section concludes the paper.

\footnotetext{
${ }^{1}$ Here it is important to note that the literature on TMTs and boards typically runs in two parallel streams (Nielsen, 2010). In addition, many studies focusing on TMTs do not specify if the TMT members are executive directors also sitting on the board or just members of the CEO's senior team. While these and related issues in the corporate governance literature render a separate discussion which is outside the remit of this paper, of interest here is strategic leadership role that both TMT and board members play in a company (Finkelstein et al., 2009). Hence these two streams of the corporate governance literature have been considered simultaneously.
} 


\section{Method: Selection of the key literature}

A systematic literature review was conducted following a methodology used by previous review studies (Nielsen, 2010; Van de Voorde et al., 2012), to ensure the process is replicable and transparent. This methodology incorporates the following seven steps: (1) specifying the focus of the review, (2) identifying key words, (3) deciding on the study period, (3) conducting key word search, (3) selecting the type of literature/journals and articles to be reviewed, and (7) a coding process.

The search for the literature was conducted using electronic databases such as: ABI/INFORM (ProQuest), Business Source Premier (EBSCO), Emerald, PsycINFO and ScienceDirect. Keywords used in this search included the terms "HRM", "HR", "people management", "work practices", "human capital", "strategic HR", "firm performance", "organisational performance", "corporate performance", "business performance" and their various combinations. Given the purpose of this paper - to provide a synthesis of the literature relating HRM to firm performance - only studies that focused on the link between HRM and firm performance were selected for the review.

The search focused on articles published in English language peer-reviewed journals from 1995 to 2017. The year 1995 was the earliest date of interest because in that year Huselid (1995) published his pioneering empirical study about HRM practices and firm performance (Van De Voorde et al., 2012; Kaufman, 2015a). A few years later Welbourne and Cyr (1999) published also a pioneering study of the relationship between the presence of human resource directors and firm performance in initial public offering firms (Chadwick et al., 2016). However, in contrast to previous reviews (for example, Boselie et al., 2005; Wright et al., 2005), which comprehensively examine the first decade of HRM-performance research, we decided to focus primarily upon 
developments in the more recent literature in an attempt to understand how the literature has since evolved.

The literature search was completed by cross-checking of the resulting list with the references of previous review studies in the field (as per Van De Voorde et al., 2012). While our review included more than 100 research studies published in this field, as well as books and papers that target mainly practitioner audience, the articles published in the following mainstream HRM journals and broader management journals with strong ties to HRM literature have been selected for a more detailed examination: Academy of Management Journal, Academy of Management Review, Human Relations, Human Resource Management, Human Resource Management Journal, Human Resource Management Review, International Journal of Human Resource Management, International Journal of Management Reviews, Journal of Management, Journal of Management Studies, and Strategic Management Journal. The choice of journals was based on the ranking of the most influential management research journals (Tahai and Meyer, 1999) and the impact of management articles (Judge et al., 2007).

The above procedure resulted in a final sample of 41 articles presented in Table A1 in the appendix. These articles were then analysed and coded by the research team. For each individual article, key themes / areas of focus and methodological approach taken (review, quantitative and qualitative) were analysed. The categorisation in Table A1 is a result of the coding process and shows three key themes / focus areas that have emerged from the analysis - HR practices, HR department and Boards/TMTs. These three themes have provided a basis around which the literature review on the HRM - firm performance link presented in this paper has been structured. 


\section{HR practices and firm performance: Designing and implementing HR practices}

\section{Designing HR practices}

The RBV of the firm (Barney, 1991; Kraaijenbrink et al., 2010; Barney et al., 2011; Kaufman, 2015a) has been used extensively in the HRM literature to explain differences in firm performance. The central argument, which contrasted with earlier more externally-focused models, is that a firm can achieve and sustain a competitive advantage through its distinctive resources and capabilities that are valuable, rare, difficult to imitate, and non-substitutable. An organisation's human capital (employees' knowledge, skills, and abilities which have economic value to organisations) has these characteristics (Paauwe, 2009; Kaufman, 2015b). A key issue is how firms manage and effectively exploit their internal pool of resources. Hence the RBV has been used as a basis for focusing investment in HR and predicting the types of investment most likely to result in superior performance and competitive advantage. However, there is disagreement regarding the core characteristics that comprise individual human capital (Wright et al., 2014), and an acknowledgement that the contribution of human capital depends on employee willingness to perform and stay in the organisation (Wright et al., 2001; Wright and McMahan, 2011; Campbell et al., 2012).

The focus thus shifts to HR related decisions and the extent to which HR practices can help create human capital advantage. Interest in human capital can be traced to the work of Becker (1964), who defined human capital as a stock of knowledge and skills. A key concern in the HRM field is how organisations can recruit employees with the right knowledge, skills, abilities and other characteristics (KSAOs) to achieve certain desired outcomes (Wright and McMahan, 2011). Additional concerns include how rewards drive employee performance, and how high performing employees can be retained by the firm to capture the benefits of their knowledge, skills, and abilities (Boxall and Purcell, 2008). In addressing these questions, it has 
been noted that from the RBV perspective individual HR practices have limited ability to generate competitive advantage in isolation: to have a synergistic impact on firm performance, particular HR practices need to be used in bundles (Darwish, 2013). Here, the literature makes a conceptual distinction between a group of HR practices and a coherent system of HR practices such as a high performance work system (HPWS) (Appelbaum et al., 2000; Huselid, 1995; Boselie et al., 2005; Posthuma et al., 2013; Kaufman, 2015a; Arthur et al., 2016; Shin and Konrad, 2017). A recent meta-analysis of longitudinal studies found that a positive association between HR practices and firm performance exists when practices are combined as high performance work practices (Saridakis et al., 2017). There is however considerable debate regarding both the characteristics of HPWS, as well as the nature of the relationship between high performance work systems and employee attitudes and behaviours (Van De Voorde and Beijer, 2015). While there are some recurring themes in the HPWS literature such as employee involvement in decision making, studies vary significantly as to the HR practices included, because various combinations support different kinds of company strategies (Becker and Huselid, 1998; Paul and Anantharaman, 2003; Wright et al., 2005; Katou and Budhwar, 2006). Thus while there is a general assumption that such systems will or can have a positive effect on performance outcomes, a detailed understanding of how and why this might be the case remains elusive.

A related debate concerns the selection and combination of HR practices so that they have the greatest impact on employee and firm performance, and two main approaches to the issue can be identified, namely a universalist/institutional/best-practices approach and a contingency/bestfit approach (Wood, 1999; Hailey at al., 2005; Kelly and Gennard, 2007; Gurbuz and Mert, 2011; Guest, 2011; Sheehan et al., 2014; Hauff et al., 2014; Brewster et al., 2016). The universalist approach uncovers a generic set of high-performance work practices, where an implicit 
assumption of benchmarking is that the effects of a best practice are generalisable, and not firm specific (McDermott et al., 2013). Typical HR practices include sophisticated recruitment, promotion of job security and extensive training and development. One example of this line of thought is Huselid (1995, p.644) who concluded that the use of high performance work practices should lead to "positive outcomes for all types of firms". An example of such an approach is the Ability, Motivation, Opportunity (AMO) model (Appelbaum et al, 2001; Boxall and Purcell, 2008; Kaufman, 2015a; Shin and Konrad, 2017). The basic premise is that employees perform well when they have the ability, motivation and opportunities to do so. As Boxall and Purcell (2008, p.173) note, "individual attributes have a huge impact but even the most able and motivated people cannot perform well if they lack the tools to finish the job or work in an unsupportive social environment". The AMO model shows how HR systems support firm performance through presenting the effects that various ability, motivation and opportunity enhancing HR practices have on employees. AMO practices are typically used in so-called commitment-based HRM systems (Chadwick et al., 2015) and are essentially the same as those identified by Van De Voorde and Beijer (2015) as common threads in the literature on high performance work systems: staffing, training, performance appraisal, pay for performance, job design, communication and participation (Chadwick et al., 2015, pp. 367-368).

The contingency approach, on the other hand, holds that particular HR practices may enhance firm performance when they are consistent with each other and work together (horizontal fit) and with the firm's strategic goals (vertical fit) (Lee et al., 2010). This approach rejects a one-size-fits-all view, and suggests instead that the effectiveness of the HRM systems depends on an organisation's external and internal context, including organisational strategy, size, labour market conditions and industry specificities (Hauff et al., 2014). From this perspective HRM policies must be "matched" with the context in which they will be applied including an 
organisational strategy (e.g. cost, quality, innovation). Though this approach has a strong logic and intuitive appeal, the empirical evidence appears to favour the Universalist approach (Combs et al., 2006; Chadwick et al., 2015), Guest (2011, p.7) calls this "an apparent contradiction between logic and evidence". The contingency perspective has also been criticised for under emphasising managerial choice and agency as well as under-emphasising the potential challenges of implementation. This relates to well established debates in the HRM literature regarding structure and agency (Gooderham et.al, 2015), the importance of HRM processes (Bowen and Ostroff, 2004; Sanders et.al, 2014), and the potential for an "intended-implemented gap" to emerge (Piening et al., 2014; Gilbert et.al, 2015; Makhecha et.al, 2016).

\section{Implementing HR practices}

In addition to the debate outlined above which primarily concerns the choice of a combination of particular HR practices that are expected to contribute to firm performance, other literature focuses upon the actual implementation of these intended HR practices. It is here where the concept of resource orchestration (Sirmon et al, 2011; Chadwick et al., 2015) comes into play. This concept refers to the capacity of managers to purposefully create, extend, or modify the resource base of an organisation, and is thus a theoretical extension of the RBV in that it explicitly acknowledges the importance of managerial action (Chadwick et al., 2015). The resource orchestration perspective suggests that it is the combination of resources, capabilities, and managerial acumen that ultimately results in superior firm performance. The managerial role as it relates to the RBV comprises three distinct dimensions: structuring (e.g., acquisition of assets), bundling (specifically tailoring resources to meet the organisation's unique needs), and leveraging (e.g., mobilizing and co-ordinating resources) (Chadwick et al., 2015). These resource 
orchestration activities can be undertaken in different ways and at different levels within the organisation ("organisational depth") (Sirmon et al., 2011).

Strategic orchestration through the depths of the organisation occurs when top managers place strategic emphasis on HRM, which reflects the importance the company's CEO places on achieving competitive advantage through leveraging HR. This is carried out by other actors within the organisation, particularly line/middle managers (Chadwick et al., 2015). This could be compared to Boxall and Purcell's (2008) model which depicts senior management intentions which are then linked to senior, HR and line management actions. These actions in turn impact on employee perceptions and responses, and through them, on firm performance. In fact, a CEO's emphasis on strategic HRM has been found to be key to the successful operationalisation of strategic HR resources (Chadwick et al., 2015). This illustrates an important role that members of the TMT play in relation to HRM.

The shift from studying the presence (design) of HR practices to how well they are implemented thus logically results in a shift in focus of the literature to line/middle managers (Townsend and Hutchinson, 2017), and how HR practices are actually received and perceived by employees (Hope Hailey et al., 2005; Guest, 2011; Piening et al., 2014). It is not HR managers but middle/line managers who are directly responsible for supervising staff and thus for implementing HR decisions and influencing employee perceptions and performance (Singh et al., 2012; Sheehan et al., 2014). Interactions between line managers and subordinate employees are crucial given that they are normally the implementers of employment policies and practices including pay, discipline, and performance (Guest et.al, 2013; Kuvass et al., 2014; Woodrow and Guest, 2014; Brewster et.al, 2015; Gilbert et.al, 2015). Since line/middle managers need to be willing and capable in this respect, the studies that focus on the relationship between HRM implementation and performance look at line manager qualities, leadership styles, interests and 
priorities, the relationship between the HR department and line managers, as well as issues around the employee psychological contract and engagement (e.g., Paauwe, 2009; McDermott et al., 2013; Alfes et al., 2013; Purcell, 2014; Cappelli, 2015).

The above means that creating value in an organisation through HRM, defined broadly as the management of work and people (Boxall and Purcell, 2008), is everyone's responsibility. Hence, the nature of relationships between HR professionals and other stakeholders in an organisation is one of partnership (Sheehan et al., 2014). Yet some studies also point to the inherent role conflict within the role of the HR professional due to the tensions resulting from having to satisfy both employee and organisational expectations. There might be a tension between maintaining an operational, consultant role for line managers focusing on the short-term, reactive issues and at the same time, taking a long-term perspective and a proactive, strategic role (Caldwell, 2003; Hope Hailey et al., 2005; Sheehan et al., 2014). The notion of role conflict has been a recurring theme in the HR literature, most notably the classic work of Legge (1978) which made a distinction between "conformist innovation", where HR managers accept conventional bottom-line measures of success, and "deviant innovation" which attempts to broaden narrow business concerns to include broader social values.

\section{HR department/profession and firm performance}

The role of the HR department / HR professional as a strategic partner (Ulrich and Brockbank, 2005; Singh et al., 2012; Martin and Gollan, 2012; Sheehan et al., 2014; Chadwick et al., 2016) has been considered in the literature on HRM - firm performance link in terms of the support this department provides to a TMT in pursuing company strategy. However, the literature also points to the possibility that some of the most critical HR decisions take place in executive suites without the input of HR professionals (Campbell et al., 2012). Interestingly, some studies (e.g., 
Chadwick et al., 2015) do not mention the HR department at all when it comes to either the design or implementation of HR practices. Whether these scholars imply or assume that HR professionals have already had an input on the board level and are contributing through that context, rather than through a separate department in a company, is another question. This raises the issue of the HR department's strategic contribution at the board, where the main areas suggested as important are the forward-looking HR metrics to support strategic decision making (details of which will be discussed later in the paper), the HR professional's expertise, as well as their ability to build relationships with senior management to understand their view when dealing with the topics that concern TMTs/boards.

From a resource dependence perspective (Pfeffer and Salancik, 1978), HR expertise and the use of HR metrics can be seen as a potential source of power for the HR department in its relationship with a TMT (Amalou-Dopke and Sub, 2014). A key assumption of the resource dependence theory is that actors do not control all the relevant resources that they need but transact with other actors in order to gain access to these resources (Hillman et al., 2009; Drees and Heugens, 2013).

Viewed from the perspective of the relationship between the HR department and the TMT, the TMT influences resource allocation through its legitimate power source - the hierarchical position in the company. The TMT is thus in a position to award - or indeed withdraw - critical resources from the HR department. At the same time, the TMT needs information from the HR department (Amalou-Dopke and Sub, 2014). Hence the power potential of the HR department is based on control over information in combination with expertise to interpret this information (Amalou-Dopke and Sub, 2014). For this power potential to transform into actual power however, the HR department needs to be able to "articulate its role in the context of short- and long-term business outcomes and put itself in the CEO's shoes" (Faragher, 
2014, p.35). Put differently, HR professionals need to be able to recognise which of their resources are relevant, that is, of most interest to top management (Cappelli, 2015), and communicate their control over those resources. Again, this reflects long standing concerns around the influence, legitimacy and power of the HR function in organisations, as well as recent attempts among many HR managers to become more influential strategic "business partners" (Kochan, 2007).

The above essentially corresponds to the three dimensions of power proposed by Hardy (1996): resource power (HR expertise), processes power (communication) and the power of meaning (assigned to HR through the provision of the relevant HR metrics). In probably the only study to date that has taken an integrative approach to examining the HRM - firm performance relationship (Sheehan et al., 2014), these three power dimensions (resource, process and meaning) have been identified as key sources of the HR professional's influence on HRM activities' potential to impact on firm performance. The power of resources identified by Sheehan et al. (2014) concern the HR department's professional expertise and having an in-house as opposed to an outsourced HR department. The power of processes concerns two dimensions: 1) HR professional ability to build relationships of trust and share information with others, and 2) TMT behavioural integration - a level of TMT's collaborative behaviour, quantity and quality of information exchanged and emphasis on joint decision making (Hambrick, 2007). TMT behavioural integration has been found to promote TMT willingness to support HRM initiatives (Sheehan et al., 2014). The power of meaning assigned to the HR department includes CEO support, HR professionals' use of business language, use of HR metrics and managing HR professional role tensions.

However, it may be naive to assume that a senior HR manager can provide information about whether HR practices are implemented or are effective (Guest, 2011). The literature points 
to ineffective use of the data on the part of HR professionals as well as confusion over HR (human capital) terminology and measures (Cappelli, 2015). The engagement and capacity for HR analytics are affected by the structural and information system obstacles within an organisation to efficient access to the data (e.g., security issues), by capability to define, analyse and model HR analytics, as well as by HR professionals' biases (e.g., feeling that data might reduce human beings to units of measurement) (CIPD and Oracle, 2013). The problem of gaining accurate HR data further influences the actions that the executives consider important (HBR, 2013).

The implications from the above consideration for the accuracy of HR information - and possibly the increased influence of HR professionals on the board / business strategy and, subsequently, firm performance - are two-fold: HR practitioners need to be able to access and use the data effectively and also actively communicate with both TMT/board members and line managers. This could be related to what Sheehan et al. (2014) refer to as an HR function's power of resources (in this case, this does not include only HR expertise but also analytical and numerical ability) and power of processes (the importance of the HR professional's role in acting as a hub in relationships and thus of the HR department's involvement in both formal and informal decision-making arenas for their impact on firm performance).

Charan et al. (2015) propose a slightly different approach to the issue of the HR's strategic influence, which, viewed from the resource dependency perspective, concerns support from the TMT to HR professionals. They suggest that the importance given to the HR department mostly depends on the CEO, since the role of the Chief Human Resources Officer (CHRO) is defined solely by the CEO. Charan et al. (2015) further argue that the CHRO role needs to be clearly designed so that a person occupying that position has a central part in the company decision-making and is properly prepared for that role. This view essentially draws on corporate 
governance literature, in particular, on studies that focus on the nature of top management team and board strategic decision making and its impact on firm performance. This literature, surprisingly, seems to be largely overlooked when studying HR as a strategic partner, yet it can provide valuable insights that may help increase our understanding of this issue and thus of the relationship between HRM and firm performance.

\section{HR metrics (workforce analytics) and firm performance}

Existing research shows that shareholders increasingly want to use HR data in combination with other perspectives on firm performance to develop a more holistic view of their investments (CIPD and PIRC, 2015). Accordingly, there is consensus that HR metrics (workforce analytics) not only need to be created in a way that will be understood by strategic leaders for the strategic decision making purposes but also incorporated in the organisation's measures of business performance to show how HR adds to the value chain and contributes to the bottom line. This is in line with the recognition of performance measurement as a multidimensional domain (Bititci et al., 2012), as particularly evidenced in development of a Balanced Scorecard (Kaplan and Norton, 1992). As a strategic performance measurement system that translates a company's vision and strategy into a coherent set of performance measures that include financial, customer, business processes and employee/HR key performance indicators, the Balanced Scorecard provides TMTs/boards with complex information at a glance, which increases a shared understanding among strategic leaders about the complexities facing their companies (Kaplan and Norton, 1992; Gimbert et al., 2010). This further enables a forum for negotiation with more informed and strategically relevant information necessary for TMT/board decisions, including the HRM related decisions. 
Apart from different types of HR metrics or "HR outcomes" (Katou and Budhwar, 2006), such as, subjective versus objective data; "input" data (e.g., staff turnover, absenteeism, cost and head count) versus "output" metrics (e.g., productivity, 360-degree feedback, employee satisfaction, training ROI, etc.), the existing literature points to a distinction between backward looking / operational performance measures used for justification and trends (that is, how well is HR doing, for example, viewed through the number of people recruited, number of training days per person and similar) and forward looking metrics for strategic planning and (planning of) implementation of HRM practices (that is, the metrics used to identify how to improve people's contribution to organisational success, such as, for example, employee engagement leading to an increase in profit) (HBR, 2013). In addition, there are calls in the literature for a more strategic set of HR metrics that are essentially related to generating HR metrics from "outside-in" (that is, starting with the market and the strategy, working back to people requirements, and only then to HR metrics) as opposed to the "inside out" approach that has been used traditionally (Huselid, 2015). Overall, the message is that HR professionals need to use the best available evidence to support strategic decision-making. This means tracking the HR metrics that are worth measuring, that is, the one that answers important strategic questions and shows evidence regarding strategic HR factors that drive business results, such as quality, customer loyalty, and financial performance (Beatty, 2015; Boudreau and Rice, 2015).

The literature also focuses on outlining various frameworks that would give a clear set of measures to understand the business value of HR. For example, the "human capital network" (Simms, 2014) outlines the analytical steps, from assessing the size and profile of the workforce, through measuring investments in human capital development and resulting capabilities, to the impact of HRM on the business. Beatty (2015) provides a detailed breakdown of the metrics that should enable HR to impact the business scorecard. In a similar vein, Schliemann (2015, p. 330) 
proposes the concept of "people equity" (not a ROI measure per se, but a strategic indicator of how well an organisation's human capital investments are paying off). The concept consists of three so called "ACE" dimensions: alignment (the extent to which individual or team goals line up within and across departments and the organisation); capabilities (the extent to which people in the organisation have the necessary competencies, information, and resources to meet customer expectations); and engagement (the extent to which people are not only committed to the organisation but also advocates for the organisation). Many companies however find it challenging to measure engagement and tie its impact to financial results (HBR, 2013). To address this problem, some companies tie customer metrics with engagement metrics, for example, the use of the service-profit chain (Heskett et al., 2008) as a tool to link engagement initiatives with business goals. This chain links internal service quality (job design, employee selection and development, rewards and recognition) with employee satisfaction. The latter is further linked to employee productivity and retention, and these in turn impact on external service value, customer satisfaction, customer loyalty and finally the firm performance (growth and profitability).

It can be inferred from the above that, to identify what needs to be measured - and therefore to increase the HR professional's ability to influence strategic decision making on the board - we need models of how HR practices contribute to the bottom line. While the literature does provide some evidence of the work being done on models connecting HR issues with firm performance outputs, the extent to which this work has been successful remains unclear. Kaufman (2015a) goes even further to argue that "omission of the logics of competition and profit making create fatal flaws in HRM analysis" (p. 123). Also, as with any analytics, HR analytics depends on data availability and data collection, and any use of such data analysis depends on the validity and reliability of the measures. The problem therefore concerns access to 
data, identifying what needs to be measured, how to measure it and how to interpret the resulting metrics. Most importantly (in relation to this paper's focus), the above consideration shows that HR metrics as one of the firm performance measurements requires an integrative approach to the HRM - performance relationship as it concerns both HR practices and the role of HR professionals. 


\section{Identifying the missing link in the literature}

TMT/board dynamics in making strategic decisions and the relationship with firm performance have been the focus of different studies in corporate governance literature (e.g., Forbes and Milliken, 1999; Carter and Lorsch, 2004; Hambrick, 2007; Petrovic, 2008; Finkelstein et al., 2009; Barton and Wiseman, 2015). However, a surprisingly small number of studies in the HRM - firm performance literature takes into account factors such as board/TMT characteristics, dynamics, and a high level of external exposure, responsibility and accountability of strategic leader role when looking at an HR professional's contribution to strategic decision making at the TMT/board level. Yet, the very nature of director role and TMT/board work can hinder making the right strategic (HR) choices even if HR professionals demonstrate strategic thinking and provide the "right" HR metrics.

The literature suggests that executives make decisions within the limits of the information that is available to them and their ability to make sense of it (Finkelstein and Hambrick, 1996). Bounded rationality is a central premise of upper echelons perspective (Hambrick and Mason, 1984; Hambrick, 2007), which posits that executives' experiences, values, and personalities greatly influence their interpretations of the situations they face and affect their strategic choices, which in turn determine firm performance. Based on this theory, Finkelstein et al. (2009, p.45) developed a model of human limits on strategic choice that explains how this "boundedness" of rationality occurs. According to the model, strategic leaders' choices result from their interpretation of strategic situations, that is, their construed reality. The strategic leader's construed reality is, in turn, a result of a filtering process, which consists of a field of vision (the directions strategic leaders look at and listen to; e.g., each director has a specific focus of attention and thus uses different information), selective perception (what the strategic leaders will 
actually see and hear), and interpretation (how the directors attach meaning to what they see and hear). The filtering process itself is influenced by the strategic leader's demographic factors (e.g., tenure, functional background and education) and their psychological characteristics (cognitive models, personality and values). Consequently, strategic leaders "act on the basis of what they know, believe, perceive and want; and these factors can vary widely from strategist to strategist" (Finkelstein et al., 2009, p. 44).

Returning to the HRM - firm performance link, Arthur et al. (2016) found that top managers' values and beliefs about the extent to which investments in high performance work systems will lead to improved firm performance will impact on adoption of these systems, as well as on their effective implementation in an organisation. However, empirical research linking TMT members' values and beliefs and the use of high performance work systems has been quite limited. As noted by Arthur et al. (2016), their study appears to be the first study to apply the upper echelons perspective to the study of high performance work systems.

The idea that strategic decision making does not follow the rational decision making model because of human limits can be traced back to the behavioural theory of the firm (Cyert and March, 1963), which suggests that managerial choices are to a large extent influenced by their natural limitations as human beings. Neuroscientists also point out that strategic decisions are made largely through unconscious processes called pattern recognition and emotional tagging (Campbell et al., 2009). This means that strategic leaders' brains assess what is happening by making assumptions based on prior experiences, and they react to that information (or ignore it) because of emotional tags that are stored in their memories.

To further complicate matters, TMTs do not really have team properties; instead they consist of "semi-autonomous barons", each engaging in bilateral relations with the CEO but having little to do with each other (Hambrick, 1994; Hambrick, 2007). If TMT members do not 
collectively engage in information processing or decision making, this implies that HR professionals need to learn how to compete. On the other hand, TMT behavioural integration is expected to have direct positive effects on firm performance (Hambrick, 2007), which could also have implications for HR professional behaviour and contribution.

Moreover, the (unitary) board of directors consists of both executives (TMT members) and non-executive directors (NEDs). This brings about a number of issues that further impact on the strategic choices made. These issues primarily relate to the executives' (CEO's) control over the selection of NEDs (the issue of NEDs skill and will to challenge executives, that is, director "reliability" as opposed to independence from management in considering strategic decisions) and the superior expertise and information available to executives given the limited time NEDs have to perform their duties (the issue of "information asymmetry" on the board) (Pettigrew and McNulty, 1995; Carter and Lorsch, 2004; Brown, 2015; Barton and Wiseman, 2015). Different forms of board composition will further have different effects on intensity and quality of directors' interactions, with implications for individual director behaviour. Complexity of relationships within a board and a complex nature of board work are "often characterised by uncertainty, incomplete information and interdependency, and where patterns of trust and distrust are often shifting” (Roberts et al., 2005, p.18).

Apart from TMT/board characteristics, specific characteristics of strategic decisions, the external environment and firm characteristics are all expected to impact on the strategic decisionmaking process and outcomes (Shepherd and Maynard, 2014). Consequently, the corporate governance literature points to a number of qualities and behaviours important for director effective contribution, including knowledge of the business, understanding of the context within which the company operates, interpersonal skills, director motivation and willingness to behave in particular ways - e.g., willingness to use their knowledge, openly communicate and 
question/challenge other directors (Petrovic, 2008). This has direct implications for the HR professional's contribution at the board level. In addition, in their tripartite model of power and influence on the board, Pettigrew and McNulty (1995, p.854) suggest that a director's ability to produce intended effects on the board depends on 1) the director's power sources (e.g., position, expertise and information), 2) the director's "will and skill" in using these power sources, and 3) the wider context and structure. This is line with the model of managerial discretion (Hambrick and Finkelstein, 1987) that proposes that the executive ability to influence firm strategic outcomes is influenced by the executive's personal characteristics (e.g., experiences, capabilities, values, psychological characteristics, power base, political acumen); the internal organisation (size, culture, availability of resources, powerful inside forces - e.g., ownership concentration); and external environment (e.g., legal constraints/ regulation, concentrated suppliers, funding sources, market growth, industry structure).

The above review shows that the corporate governance literature provides insights into the issues that need to be taken into account when considering HR professionals' impact on making strategic HR choices at the board and the performance outcomes of such decisions. These issues reflect the multilevel nature of TMT/board work (individual / group /organisational /external environment). This primarily concerns bounded rationality / human limits / neuroscience aspects of TMT/board director behaviour, the specific nature of TMT and board dynamics, a high level of accountability and responsibility of the strategic leader's role, the role expectations influenced by specific firm and external environment characteristics, and individual director demographic and psychological characteristics. It is thus argued that in making strategic HR decisions it is important to take into account the issues of TMT/board dynamics, as well as limited rationality of TMT/board members. Strategic leaders only attend to a portion of what they are watching and really hear only a portion of what they are listening. Moreover, as a group of 
people charged with the responsibility and accountability for the overall operation of an organisation, TMTs and boards have specific properties that result in complex dynamics which impacts on strategic decisions made. This means that even if the TMT/board is supplied with the "perfect" HR information and has "perfectly knowledgeable" directors (including the HR director), it cannot be expected that a logical, obvious set of strategic HR choices will be made.

Issues resulting from the presence of people with different demographic and psychological characteristics and thus their different views and expectations will therefore exist in both HR planning/design and implementation phases. Yet the HRM literature tends to explicitly acknowledge this "human side of business" only when it comes to implementation of HR practices, by pointing out that even if "brilliant" strategic HR choices are made, this is not a guarantee these choices will result in outstanding firm performance as it is the implementation of HR decisions that may stand in the way. The upper echelons perspective and corresponding models of human limits on strategic choice, managerial discretion and behavioural integration, as well as the tripartite model of power and influence on the board, are some of the key theoretical approaches in the corporate governance literature that could help us increase our understanding of the HRM - performance relationship by offering explanations about how and why particular strategic (HR) decisions are made on the board.

\section{Discussion: An integrated framework of the firm-performance relationship}

We have demonstrated the presence of several streams of the research into the HRM - firm performance relationship: designing HR practices, implementing HR practices, the contribution of the HR department to strategic decision making on the board, and different workforce analytics and measures of HR contribution to firm performance. The paper also identifies a gap a missing link - that concerns the importance of incorporating insights from corporate governance 
literature when considering strategic HR decision making. The HRM - firm performance framework that integrates HRM and corporate governance literatures and draws on the multiple theoretical perspectives is presented in Figure 1.

[Figure 1 about here]

The framework outlines two stages that concern the HRM - performance relationship. One is a design stage which concerns strategic HR decisions, that is, intended HR practices. The other is the implementation stage. Looking across both stages, the framework depicts different organisational roles (HR professional, TMT/board members, line managers and employees), their interactions in different HRM stages (HR design/strategic choices and implementation) and contribution to firm performance. The lines in the framework present a flow of information / direction of communication (DC) between actors in different roles.

In the design stage, DC1 presents the communication from the Board / TMT to the HR department. The assumption is that HR decisions are aligned with the corporate strategy and result from the HR department/HR professional's involvement in strategic decision making on the board. This stage is explained by $\mathrm{RBV}$, resource dependence, board power and upper echelons perspectives.

In the implementation stage, the emphasis is on the role of line managers and employees and respective HR outcomes evidenced through the HR metrics. This stage is explained by resource orchestration perspective and involves communication from both TMT (DC2) and the HR department (DC3) to line managers.

Information about HR outcomes (HR metrics) and any other information that concerns employees / the implementation stage is fed back by line managers to the HR department (DC4). 
The HR metrics is then provided by the HR department to the TMT/board (DC5), who then review this together with the overall firm performance

Following the integrative framework, the HRM - performance relationship can be explained not only through the HR professionals' provision of the relevant HR metrics and expert advice in making strategic HR choices on the board, or through addressing various issues in implementing the chosen HR practices. The integrative approach presented in the framework is essentially about development of a shared vision of HRM in an organisation and shared commitment to its implementation through active communication of expectations/subjective views (construed reality) about HRM between HR professionals, TMT/board members, line managers and other stakeholders/people in the HR professional's role set. The framework thus takes into account the issues that concern both strategic planning and implementation of HR practices. This bridges a current divide between the literatures that focus on HR as practices and $\mathrm{HR}$ as the department/profession, and also incorporates important insights from the corporate governance literature.

\section{Implications for theory and practice}

A significant contribution of this paper to theory is to propose an integrative framework that conceptualises the elusive relationship between HRM and firm performance, and which draws on different literatures and multiple theoretical perspectives in to offer more holistic insights into the relationship. A way forward is to encourage greater complementarities both within the HRM discipline itself given the different ways HR scholars conceptualise and operationalise issues of HRM and performance. Building of greater links with other disciplinary areas such as corporate governance may also aid our understanding of the role of HR department/professionals in contributing to strategic decision making at the TMT/board level and through that, to firm 
performance. This is particularly important in view of the increasing recognition that effective HRM should be treated as a strategic board level issue because of its impact on firm performance. In effect, it could be argued that firm performance, as a common "denominator", could serve as a basis for connecting two separate debates that have been running in parallel - one on the impact of corporate governance mechanisms (board directors / strategic leaders) on firm performance, the other on the impact of HRM on firm performance. In more practical terms, it has been suggested that if HR issues are to be taken seriously HR needs a presence on the board. Caldwell (2011) suggests that there is an association between HR specialists being a member of the board and CEOs viewing HR in a positive way. Yet the extent to which HR specialists have reinvented themselves as highly valued strategic business partners is questionable. Kochan (2004) suggests that the HR profession continues to face a crisis of trust and loss of legitimacy in the eyes of its major stakeholders, while Thompson (2011) argues that even the best-intentioned HR specialists might find their efforts derailed by an emphasis upon narrow short-term financial imperatives. This is not to say, however, that board membership guarantees greater HR influence or that it is essential for HR to have a strong influence. It is also possible that some board members yield greater influence than others (Kelly and Gennard, 2007).

Each of the theoretical perspectives around the HRM - performance relationship presented in the framework also has a direct implication for practice:

- HR practices: Which individual practices - or combinations of HR practices - have the most impact on firm performance and are thus worth investment and development, to what extent are practices context-specific or universally applicable, and how can practices be coherently combined? (resource based view)

- HR implementation: How can firms ensure the effective implementation of HR practices and policies, usually by line managers, and the extent to which they are delivered and enacted as 
intended, and thus also how they are received and perceived by employees? (resource orchestration perspective)

- HR influence: What HR metrics, qualities, behaviours, skills and expertise do HR professionals need to bring to the boardroom to gain greater credibility and influence in the strategic decision making of organisations? (resource dependence / board power and upper echelons perspectives) 


\section{Conclusion}

While there has been great research interest in the topic of the HRM - performance relationship for at least two decades, making an important distinction between HRM practices and the role of the HR department, our understanding of the nature of the linkages remains limited. In this paper we suggest that in part this is because of the different approaches evident from a view of the extant literature. Our central argument is that this means that despite extensive and methodologically sophisticated research evidence, our understanding remains partial and incomplete; though many scholars have investigated the HR-performance link, they are not necessarily always talking about the same thing. To this end, this paper has reviewed the literature on the HRM - firm performance relationship and argues that our understanding of the mechanisms through which HR decisions create and sustain value in an organisation can be improved by a better integration of the literatures on $H R$ practices and $H R$ professionals/department, and by adding a missing link to the insights offered in the corporate governance literature. Specifically, this paper incorporates some key corporate governance literature on boards and top management teams (TMTs) that has been considered in some studies of the HRM - firm performance relationship and provides a much needed synthesis of the literature relating HR to firm performance and the moderating role of CG.

Our work highlights the importance of HR professionals actively connecting to key stakeholders and understanding their expectations for both creating value of HR practices for the organisation, as well as increasing the profile of the HR department. In view of the rapid changes across the world in terms of customer needs, competition, and regulation, this would be a good opportunity for HR professionals to provide evidence to TMTs/boards and shareholders that HRM is at the heart of driving firm performance, and to demonstrate their own value added to the delivery of this. However, the existing evidence suggests that in reality HR specialists continue to 
face a crisis of trust and legitimacy in organisations, despite decades of research concerning more 'strategic human resource management' and attempts to reinvent HR specialists as strategically focused 'business partners', and that even well intentioned HR policies can be derailed by the pressures to meet short-term financial imperatives. 


\section{References}

Alfes, K., Shantz, A., Truss, C. and Soane, E. (2013). The link between perceived human resource management practices, engagement and employee behaviour: a moderated mediation model. International Journal of Human Resource Management 24(2). pp. 330351.

Amalou-Dopke, L. and Sub, S. (2014). HR measurement as an instrument of the HR department in its exchange relationship with top management: A qualitative study based on resource dependence theory. Scandinavian Journal of Management 30. pp. 444-460.

Applebaum, E., Bailey, T., Berg, P., \& Kalleberg, A. L. (2001). Do high performance work systems pay off? In S. P. Vallas (Ed.), The transformation of work: Research in the sociology of work (Vol. 10, pp. 85-107). Oxford, UK: Emerald Group Publishing Limited.

Appelbaum, E., Bailey, T., Berg, P. and Kalleberg, A. L. (2000). Manufacturing Advantage: Why High-Performance Work Systems Pay Off.Manufacturing Advantage: Why HighPerformance Work Systems Pay Off Ithaca, NY: Cornell University Press.

Arthur, J.B., Herdman, A.O., and Yang, J. (2016). How top management HR beliefs and values affect high-performance work system adoption and implementation effectiveness. Human Resource Management 55(3). pp. 413-435.

Barney J. (1991). Firm resources and sustained competitive advantage. Journal of Management 17(1). pp. 99-120.

Barney, J.B., Ketchen, D.J., and Wright, M. (2011). The future of resource-based theory: revitalisation or decline? Journal of Management 37. pp. 1299-1315.

Barton, D. and Wiseman, M. (2015). Where boards fall short: New data shows that most directors don't understand the company's strategy. Harvard Business Review 93(1). pp. 98-104. 
Beatty, R.W. (2015). HR analytics and metrics: scoring on the business scorecard. In Ulrich, D., Schiemann, B., and Sartain, L (Eds.). The Rise of HR. Alexandria, VA: HR Certification Institute. pp. 285-294.

Becker, B. and Gerhart, B. (1996). The impact of human resource management on organizational performance: progress and prospects. Academy of Management Journal 39(4), pp. 779801.

Becker, B.E. and Huselid, M. (1998). High performance work systems and firm performance: a synthesis of research and managerial implications. Research in Personnel and Human Resource Management 16. pp. 53-101.

Becker, G.S. (1964). Human capital theory. New York: Columbia.

Beer, M. (2015). HRM at a crossroads: Comments on "Evolution of strategic HRM through two founding books: A 30th anniversary perspective on development of the field". Human Resource Management 54(3). pp. 417-421

Bititci, U., Garengo, P., Dörfler, V., and Nudurupati, S. (2012). Performance measurement: Challenges for tomorrow. International Journal of Management Reviews 14(3). pp. 305327.

Boselie, P., Dietz, G. and Boon, C. (2005). Commonalities and contradictions in HRM and performance research. Human Resource Management Journal 15. pp. 67-94.

Boudreau, J. and Rice, S. (2015). Bright, shiny objects and the future of HR. Harvard Business Review. July-August. Pp. 72-78.

Bowen, D. E. and Ostroff, C. (2004). Understanding HRM-firm performance linkages: The role of 'strength' of the HRM system. Academy of Management Review, 29, pp. 203-221.

Boxall, P. and Purcell, J. (2008). Strategy and Human Resource Management. 2nd ed. Basingstoke: Palgrave Macmillan. 
Brewster, C., Gooderham, P.N. and Mayrhofer, W. (2016). Human resource management: the promise, the performance, the consequences. Journal of Organizational Effectiveness: People and Performance 3(2). pp.181- 190.

Brown, J.R. (2015). The demystification of the board of directors. American Business Law Journal. 52(1). pp. 131-200.

Caldwell, R. (2011). HR directors in UK boardrooms: a search for strategic influence or symbolic capital?. Employee Relations, 33(1), pp.40-63.

Caldwell, R. (2003). The changing roles of personnel managers: old ambiguities, new uncertainties. Journal of Management Studies 40. pp. 983-1004.

Campbell, A., Whitehead, J., and Finkelstein, S. (2009). Why good leaders make bad decisions. Harvard Business Review February. pp. 60-66.

Campbell, B.A., Russell, C., Kryscynski, D. (2012). Rethinking sustained competitive advantage from human capital. Academy of Management Review 37(3). pp. 376-395.

Cappelli, P. (2015). Why we love to hate HR... and what HR can do about it. Harvard Business Review July-August. pp. 54-61.

Carter, C.B. and Lorsch, J. (2004). Back to the Drawing Board. Cambridge, Massachusetts: Harvard Business School Publishing.

Cascio, W.F. (2015). Strategic HRM: Too important for an insular approach. Human Resource Management 54(3). pp. 389-407.

Chadwick, C, Super, J.F. and Kwon, K. (2015). Resource orchestration in practice: CEO emphasis on SHRM, commitment-based HR systems, and firm performance. Strategic Management Journal 36. pp. 360-376.

Chadwick, C., Guthrie, J.P. and Xing, X. (2016). The HR executive effect on firm performance and survival. Strategic Management Journal 37(11), pp.2346-2361. 
Charan, R., Barton, D., and Carey, D. (2015). People before strategy: a new role for the CHRO. Harvard Business Review July-August. pp. 62-71.

Chowhan, J. (2016). Unpacking the black box: understanding the relationship between strategy, HRM practices, innovation and organizational performance. Human Resource Management Journal 26(2). pp. 112-133.

CIPD and Oracle (2013). Talent Analytics and Big Data - The Challenge for HR. CIPD Research Report. November. London: CIPD.

CIPD and PIRC (2015). Human Capital Reporting: Investing for Sustainable Growth. CIPD Research Report. January. London: CIPD.

Combs, J., Liu Y., Hall, A, and Ketchen, D. (2006). How much do high-performance work practices matter? A meta-analysis of their effects on organisational performance. Personnel Psychology 59(3). pp. 501-528.

Cyert, R.M. and March, J.A. (1963). A Behavioural Theory of the Firm. Englewood Cliffs, NJ: Prentice-Hall.

Darwish, T.K. (2013). Strategic HRM and Performance: Theory and Practice. Newcastle upon Tyne: Cambridge Scholars Publishing.

Darwish, T.K., Singh, S. and Wood, G. (2016). The Impact of Human Resource Practices on Actual and Perceived Organizational Performance in a Middle Eastern Emerging Market. Human Resource Management 55(2). pp. 261-281.

Drees, J.M., and Heugens, P.P.M.A.R. (2013). Synthesizing and extending Resource Dependence theory: A meta-analysis. Journal of Management 39. pp. 1666-1698.

Faragher, J. (2014). The 5 most difficult conversations you'll have at work...made easy. People Management. March. pp.32-36. 
Finkelstein, S., and Hambrick, D.C. (1996). Strategic leadership: Top Executives and Their Effects on Organizations. St. Paul: West Educational Publishing.

Finkelstein, S., Hambrick, D.C., and Cannella, B. (2009). Strategic Leadership: Theory and Research on Executives, Top Management Teams, and Boards. Oxford: Oxford University Press.

Forbes, D.P., and Milliken, F.J. (1999) Cognition and corporate governance: Understanding boards of directors as strategic-decision making groups, Academy of Management Review 24(3): 489-505

Gimbert, X, Bisbe, J. and Mendoza, X (2010). The role of performance measurement systems in strategy formulation processes. Long Range Planning 43. pp. 477-497.Gilbert, C., De Winne, S. and Sels, L. (2015). Strong HRM processes and line managers' effective HRM implementation: a balanced view. Human Resource Management Journal, 25(4), pp. 600616.

Gooderham, P., Fenton-O'Creevy, M., Croucher, R. and Brookes, M. (2015). A multilevel analysis of the use of individual pay-for-performance systems. Journal of Management, DOI: $10.1177 / 0149206315610634$.

Guest, D. (2005). Conference Session 5. Human Resource Management and Corporate Performance: Recent Empirical Evidence. In Filatotchev , I., Guest, D., Piesse, J., Jackson, G., and Gospel, H. (2005). Corporate Governance, Human Resource Management and Firm Performance. DTI Economics Working Paper No. 13. Available at SSRN: https://ssrn.com/abstract=906023 or http://dx.doi.org/10.2139/ssrn.906023. pp. 101-112. 
Guest, D. E and Bos-Nehles, A. C. (2013). HRM and performance: The role of effective implementation. In J. Paauwe, D. E. Guest, \& P. W. Wright (Eds.), HRM and performance: Achievements and challenges (pp. 79-96). Chichester: Wiley.

Guest, D.E. (2011). Human resource management and performance: still searching for some answers. Human Resource Management Journal 21(1). pp. 3-13.

Gurbuz, S. and Mert, I.S. (2011). Impact of the strategic human resource management on organisational performance: evidence from Turkey. International Journal of Human Resource Management 22(8). pp.1803-1822.

Hambrick, D.C. (1994). Top management groups: A conceptual integration and reconsideration of the team label. In B. M. Staw and L. L. Cummings (Eds.), Research in organizational behavior 16. pp. 171-214. Greenwich, CT: JAI Press.

Hambrick, D.C. (2007). Upper echelons theory: an update. Academy of Management Review 32(2). pp. 334-343.

Hambrick, D.C., and Finkelstein, S. (1987). Managerial discretion: A bridge between polar views of organizational outcomes. Research in Organizational Behavior 9. pp. 369- 406. Greenwich, CT: JAI Press.

Hambrick, D.C., and Mason, P.A. (1984). Upper echelons: The organization as a reflection of its top managers. Academy of Management Review 9. pp. 193-206.

Hardy, C. (1996). Understanding power: bringing about strategic change. British Journal of Management 7(S). pp. S3-S16.

Hauff, S., Alewell, D. and Hansen, N.K. (2014). HRM systems between control and commitment: occurrence, characteristics and effects on HRM outcomes and firm performance. Human Resource Management Journal 24(4). pp. 424-441. 
HBR (2013). The Impact of Employee Engagement on Performance. A Harvard Business Review Analytics Services Report. Cambridge, MA: Harvard Business School Publishing.

Heskett, J.L., Jones, T.O., Loveman, G.W., Sasser, W.E.Jr., and Schlesinger, L.A. (2008). Putting the Service-Profit Chain to Work. Harvard Business Review. July-August. pp. 118-129.

Hillman, A.J., Withers, M.C., and Collins, B.J. (2009). Resource dependence theory: A review. Journal of Management 35. pp. 404-427.

Hope Hailey, V., Farndale, E., and Truss, C. (2005). The HR department's role in organisational performance. Human Resource Management Journal 15(3). pp. 49-66.

Huselid, M. (2015). Workforce analytics for strategy execution. In Ulrich, D., Schiemann, B., and Sartain, L (eds.). The Rise of HR. Alexandria, VA: HR Certification Institute. pp. 309316.

Huselid, M.A. (1995). The impact of human resource management practices on turnover, productivity, and corporate financial performance. Academy of Management Journal 38. pp. 635-672.

Judge, T.A., Cable, D.M., Colbert, A.E. and Rynes, S. (2007). What causes a management article to be cited - Article, author, or journal? Academy of Management Journal 50. pp. 491506.

Kaplan, R.S. and Norton, D.P. (1992). The Balanced Scorecard - measures that drive performance. Harvard Business Review January- February. pp. 71-79.

Katou, A. and Budhwar, P.S. (2006). Human resource management systems and organizational performance: a test of a mediating model in the Greek manufacturing context. International Journal of Human Resource Management 17. pp. 1223-1253. 
Kaufman, B.E. (2015a). Market competition, HRM, and firm performance: The conventional paradigm critiqued and reformulated. Human Resource Management Review 25 (2015) $107-125$

Kaufman, B.E. (2015b) Evolution of Strategic HRM as seen through two founding books: A 30th anniversary perspective on development of the field. Human Resource Management 54(3). pp. 389-407.

Kelly, J., and Gennard, J. (2007). Business strategic decision making: the role and influence of directors. Human Resource Management Journal 17(2). pp. 99-117.

Kochan, T.A. (2007). Social legitimacy of the HRM profession: A US perspective. Oxford Handbook of Human Resource Management, Oxford University Press, Oxford, p.599.

Kochan, T.A. (2004). Restoring trust in the human resource management profession. Asia Pacific Journal of Human Resources, 42(2), pp.132-146.

Kraaijenbrink, J., Spender, J.C., and Groen, A.J. (2010). The resource-based view: a review and assessment of its critiques. Journal of Management 36(1). pp. 349-372.

Kuvaas, B., Dysvik, A. and Buch, R. (2014). Antecedents and employee outcomes of line managers' perceptions of enabling HR practices. Journal of Management Studies, 51(6), pp.845-868.

Lee, F.H., Lee, T.Z., and Wu, W.Y. (2010). The relationship between human resource management practices, business strategy and firm performance: evidence from steel industry in Taiwan. International Journal of Human Resource Management 21(9). pp. $1351-1372$.

Legge, K. (1978). Power, innovation, and problem-solving in personnel management. MacGrawHill Book Company. 
Makhecha, U.P., Srinivasan, V., Prabhu, G.N. and Mukherji, S. (2016). Multi-level gaps: a study of intended, actual and experienced human resource practices in a hypermarket chain in India. The International Journal of Human Resource Management, pp.1-39.

Martin, G. and Gollan, P.J. (2012). Corporate governance and strategic human resources management in the UK financial services sector: the case of the RBS. International Journal of Human Resource Management 23(16). pp. 3295-3314.

McDermott, A.M., Conway, E., Rousseau, D.M., and Flood, P.C. (2013). Promoting effective psychological contracts through leadership: the missing link between HR strategy and performance. Human Resource Management 52(2). pp. 289-310

Nielsen, S. (2010). Top management team diversity: A review of theories and methodologies, International Journal of Management Reviews 12(3). pp. 301-316.

Paauwe, J. (2009). HRM and performance: Achievements, methodological issues and prospects. Journal of Management Studies 46(1). pp. 129-142.

Paauwe, J. Guest, D. and Wright, P. eds., (20132). HRM and performance: Achievements and challenges. New York: John Wiley \& Sons.

Paul, A.K. and Anantharaman, R.N. (2003). Impact of people management practices on organizational performance: analysis of a causal model. International Journal of Human Resource Management 14. pp. 1246-1266.

Petrovic, J. (2008). Unlocking the role of a board director: A review of the literature. Management Decision 46(9) (Emerald/EFMD ODRA Winning Paper), pp. 1373-1392.

Pettigrew, A. and McNulty, T. (1995). Power and influence in and around the boardroom. Human Relations 48(8). pp. 845-873.

Pfeffer. J., and Salancik, G. (1978). The External Control of Organizations: A Resourcedependence Perspective. New York: Harper \& Row. 
Piening, E.P., Baluch, A.M. and Ridder, H.G. (2014). Mind the Intended-Implemented Gap: Understanding Employees' Perceptions of HRM. Human Resource Management, 53(4), pp.545-567.

Posthuma, R.A., Campion, M.C., Masimova, M., and Campion, M.A. (2013). A high performance work practices taxonomy: integrating the literature and directing future research. Journal of Management 39(5). pp. 1184-1220.

Purcell, J. (2014). Disengaging from engagement. Human Resource Management Journal. 24(3). pp. $241-254$.

Roberts, J., McNulty, T. and Stiles, P. (2005). Beyond agency conceptions of the work of the non-executive director: Creating accountability in the boardroom. British Journal of Management 16(Special issue), 5-26.

Sanders, K., Shipton, H. and Gomes, J.F. (2014). Guest editors' introduction: Is the HRM process important? Past, current, and future challenges. Human Resource Management, 53(4), pp.489-503.

Saridakis, G., Yanqing, L. and Cooper, C. (2017). Exploring the relationship between HRM and firm performance: a meta-analysis of longitudinal studies. Human Resource Management Review, 27(1), pp. 87-96.

Schiemann, W.A. (2015). Optimizing talent: HR's key role for tomorrow. in Ulrich, D., Schiemann, B., and Sartain, L (eds.). The Rise of HR. Alexandria, VA: HR Certification Institute. pp. 329-335.

Sheehan, C., De Cieri, H., Cooper, B., and Brooks, R. (2014). Exploring the power dimensions of the human resource function. Human Resource Management Journal 24(2). pp. 193-210. 
Shepherd, N.G. and Maynard, R.J. (2014). The influence of context on the strategic decisionmaking process: A review of the literature. International Journal of Management Reviews 16(3). pp. 340-364.

Shin, D. and Konrad, A.M. (2017). Causality Between High-Performance Work Systems and Organizational Performance. Journal of Management 43(4). pp. 973-997.

Simms, J. (2014). Meet HR's new stat squad. People Management. July. pp. 30-34.

Singh, S., Darwish, T.K., and Anderson, N. (2012). Strategic intent, high-performance HRM, and the role of the HR director: an investigation into attitudes and practices in the country of Jordan. International Journal of Human Resource Management 23 (14). pp. $3027-$ 3044.

Sirmon, D.G., Hitt, M.A., Ireland, R.D., Gilbert, B.A. (2011). Resource orchestration to create competitive advantage. Journal of Management 37(5). pp. 1390-1412.

Tahai, A. and Meyer, M.J. (1999). A revealed preference study of management journal direct influences. Strategic Management Journal 20. pp. 279-296.

Thompson, P. (2011). The trouble with HRM. Human Resource Management Journal, 21(4), pp.355-367.

Townsend, K. and Hutchinson, S. (2017). Line managers in industrial relations: Where are we now and where to next?. Journal of Industrial Relations, p.0022185616671163.

Ulrich, D., and Brockbank, W. (2005). The HR Value Proposition. Cambridge, MA: Harvard Business Review Press.

Ulrich, D., Schiemann, B., and Sartain, L (Eds.) (2015). The Rise of HR. Alexandria, VA: HR Certification Institute. 
Van De Voorde, K., Paauwe, J., and Van Veldhoven, M. (2012). Employee well-being and the HRM-organizational performance relationship: A review of quantitative studies. International Journal of Management Reviews 14. pp. 391-407.

Van De Voorde, K., and Beijer, S. (2015). The role of employee HR attributions in the relationship between high-performance work systems and employee outcomes. Human Resource Management Journal 25(1). pp 62-78.

Wall, T.D. and Wood, S.J. (2005). The romance of human resource management and business performance, and the case for big science. Human Relations 58. pp. 429-462

Welbourne, T.M. and Cyr, L.A. (1999). The human resource executive effect in initial public offering firms. Academy of Management Journal 42(6). pp 616-629.

Wood, S.J. (1999). Human resource management and performance. International Journal of Management Reviews 1. pp. 367-413.

Woodrow, C. and Guest, D. E. (2014). When good HR gets bad results: Exploring the challenge of HR implementation in the case of workplace bullying. Human Resource Management Journal, 24, pp.38-56.

Wright, P.M and McMahan, G.C. (2011). Exploring human capital: putting human back into strategic human resource management. Human Resource Management Journal. 21(2). pp. 93-104.

Wright, P.M., Coff, R., and Moliterno, T.P. (2014). Strategic human capital: crossing the great divide. Journal of Management 40(2). pp. 353-370.

Wright, P.M., Dunford, B.B. and Snell, S.A. (2001). Human resources and the resource based view of the firm. Journal of Management 27(6). pp. 701-721. 
Wright, P.M., Gardner, T.M., Moynihan, L.M., and Allen, M.R. (2005). The relationship between HR practices and firm performance: examining causal order. Personnel Psychology 58(2). pp. $409-446$. 
Figure 1: An integrative framework of the HRM - firm performance relationship

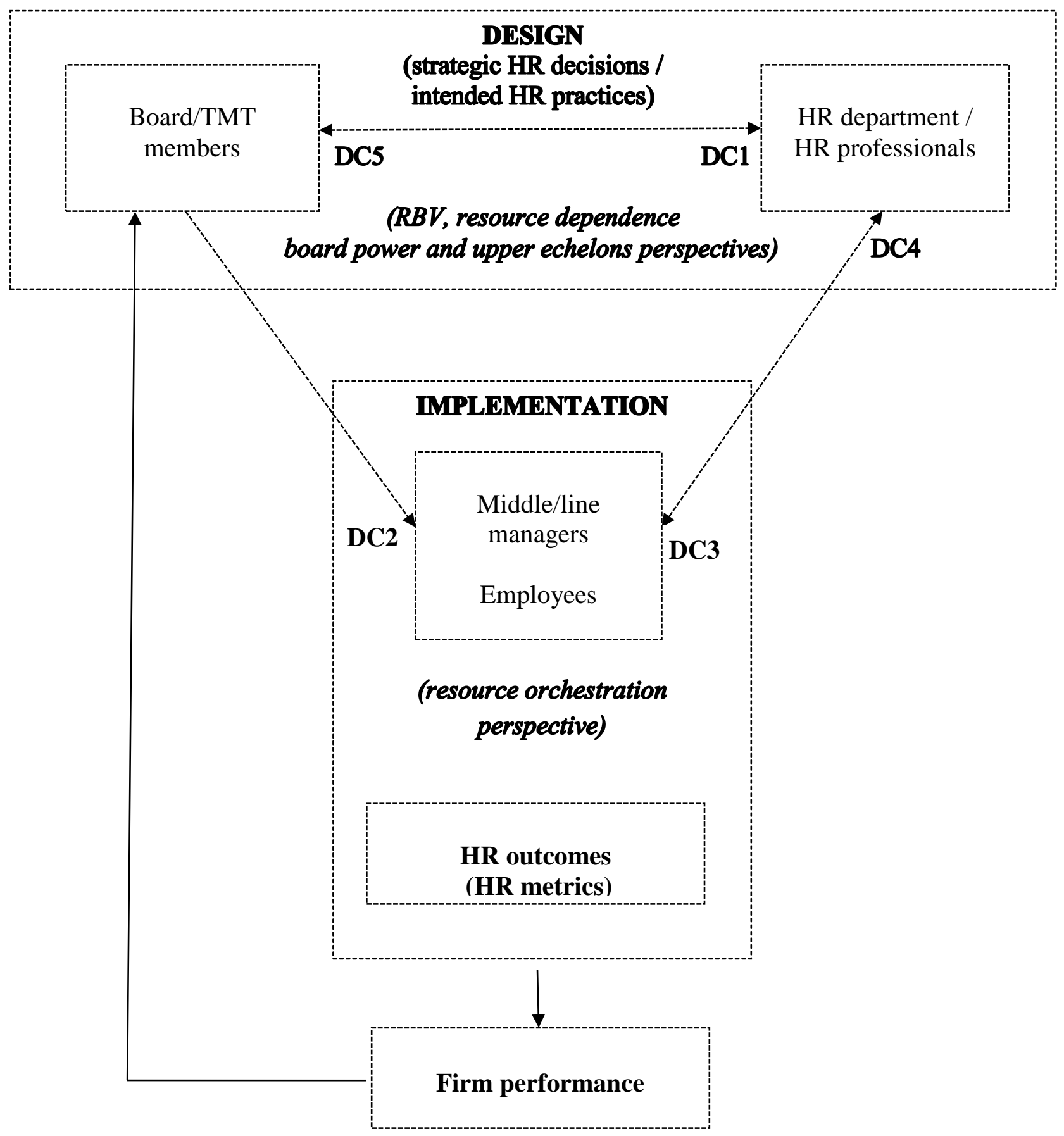




\section{Appendix}

\section{Table A1: A selection of the literature on the HRM - firm performance link}

\begin{tabular}{|c|c|c|c|c|c|c|}
\hline \multirow[b]{3}{*}{ Article reference } & \multicolumn{4}{|c|}{ Focus } & \multirow[t]{3}{*}{ Approach } & \multirow[t]{3}{*}{ Journal } \\
\hline & \multicolumn{2}{|c|}{$\begin{array}{c}\text { HR practices } \\
\text { (processes/systems/ } \\
\text { policies/strategies) }\end{array}$} & \multirow{2}{*}{$\begin{array}{c}\text { HR } \\
\text { department/ } \\
\text { profession } \\
\text { Contribution } \\
\text { to strategic } \\
\text { decision } \\
\text { making on the } \\
\text { board }\end{array}$} & \multirow{2}{*}{$\begin{array}{c}\begin{array}{c}\text { Corporate } \\
\text { governance }\end{array} \\
\text { Nature of } \\
\text { strategic } \\
\text { decision } \\
\text { making and } \\
\text { TMT/board } \\
\text { dynamics } \\
\end{array}$} & & \\
\hline & Design & Implementation & & & & \\
\hline Alfes et al., 2013 & & $\mathrm{x}$ & & & Quantitative & $\begin{array}{l}\text { International Journal } \\
\text { of Human Resource } \\
\text { Management }\end{array}$ \\
\hline Arthur et al., 2016 & $\mathrm{x}$ & $\mathrm{x}$ & & $\mathrm{x}$ & Quantitative & $\begin{array}{l}\text { Human Resource } \\
\text { Management }\end{array}$ \\
\hline $\begin{array}{l}\text { Becker and } \\
\text { Gerhart, } 1996\end{array}$ & $\mathrm{x}$ & & & & Review & $\begin{array}{l}\text { Academy of } \\
\text { Management Journal }\end{array}$ \\
\hline $\begin{array}{l}\text { Boselie et al., } \\
2005\end{array}$ & $\mathrm{x}$ & & & & Review & $\begin{array}{l}\text { Human Resource } \\
\text { Management Journal }\end{array}$ \\
\hline $\begin{array}{l}\text { Bowen and } \\
\text { Ostroff, } 2004\end{array}$ & $\mathrm{x}$ & & & & Review & $\begin{array}{l}\text { Academy of } \\
\text { Management Review }\end{array}$ \\
\hline Caldwell, 2003 & & $\mathrm{x}$ & $\mathrm{x}$ & & $\begin{array}{l}\text { Quantitative and } \\
\text { qualitative }\end{array}$ & $\begin{array}{l}\text { Journal of } \\
\text { Management Studies }\end{array}$ \\
\hline $\begin{array}{l}\text { Campbell et al., } \\
2012\end{array}$ & $\mathrm{x}$ & & $\mathrm{x}$ & & Review & $\begin{array}{l}\text { Academy of } \\
\text { Management Review }\end{array}$ \\
\hline $\begin{array}{l}\text { Chadwick et al., } \\
2015\end{array}$ & $\mathrm{x}$ & $\mathrm{x}$ & & & Quantitative & $\begin{array}{l}\text { Strategic Management } \\
\text { Journal }\end{array}$ \\
\hline $\begin{array}{l}\text { Chadwick et al., } \\
2016\end{array}$ & & & $\mathrm{x}$ & & Quantitative & $\begin{array}{l}\text { Strategic Management } \\
\text { Journal }\end{array}$ \\
\hline Chowhan, 2016 & & & & & Quantitative & $\begin{array}{l}\text { Human Resource } \\
\text { Management Journal }\end{array}$ \\
\hline Combs et al., 2006 & $\mathrm{x}$ & & & & Review & Personnel Psychology \\
\hline $\begin{array}{l}\text { Darwish et al. } \\
2016\end{array}$ & $\mathrm{x}$ & & & & Quantitative & $\begin{array}{l}\text { Human Resource } \\
\text { Management }\end{array}$ \\
\hline Guest, 2011 & $\mathrm{x}$ & $\mathrm{x}$ & & & Review & $\begin{array}{l}\text { Human Resource } \\
\text { Management Journal }\end{array}$ \\
\hline $\begin{array}{l}\text { Gurbuz and Mert, } \\
2011\end{array}$ & $\mathrm{x}$ & & & & Quantitative & $\begin{array}{l}\text { International Journal } \\
\text { of Human Resource } \\
\text { Management }\end{array}$ \\
\hline Hauff et al., 2014 & $\mathrm{x}$ & & & & Quantitative & $\begin{array}{l}\text { Human Resource } \\
\text { Management Journal }\end{array}$ \\
\hline $\begin{array}{l}\text { Hope Hailey et al., } \\
2005\end{array}$ & $\mathrm{x}$ & $\mathrm{x}$ & $\mathrm{x}$ & & $\begin{array}{l}\text { Qualitative and } \\
\text { quantitative }\end{array}$ & $\begin{array}{l}\text { Human Resource } \\
\text { Management Journal }\end{array}$ \\
\hline Huselid, 1995 & $\mathrm{x}$ & & & & Quantitative & $\begin{array}{l}\text { Academy of } \\
\text { Management Journal }\end{array}$ \\
\hline $\begin{array}{l}\text { Katou and } \\
\text { Budhwar, } 2006\end{array}$ & $\mathrm{x}$ & & & & Quantitative & $\begin{array}{l}\text { International Journal } \\
\text { of Human Resource } \\
\text { Management }\end{array}$ \\
\hline Kaufman, 2015a & $\mathrm{x}$ & & & & Review & $\begin{array}{l}\text { Human Resource } \\
\text { Management Review }\end{array}$ \\
\hline Kaufman, 2015b & $\mathrm{x}$ & & & & Review & $\begin{array}{l}\text { Human Resource } \\
\text { Management }\end{array}$ \\
\hline $\begin{array}{l}\text { Kelly and } \\
\text { Gennard, } 2007\end{array}$ & $\mathrm{x}$ & & $\mathrm{x}$ & & Qualitative & $\begin{array}{l}\text { Human Resource } \\
\text { Management Journal }\end{array}$ \\
\hline Lee et al., 2010 & $\mathrm{x}$ & & & & Quantitative & $\begin{array}{l}\text { International Journal } \\
\text { of Human Resource }\end{array}$ \\
\hline
\end{tabular}




\begin{tabular}{|c|c|c|c|c|c|c|}
\hline & & & & & & Management \\
\hline $\begin{array}{l}\text { Martin and } \\
\text { Gollan, } 2012\end{array}$ & & & $\mathrm{x}$ & $\mathrm{x}$ & Qualitative & $\begin{array}{l}\text { International Journal } \\
\text { of Human Resource } \\
\text { Management }\end{array}$ \\
\hline $\begin{array}{l}\text { McDermott et al., } \\
2013\end{array}$ & $\mathrm{x}$ & $\mathrm{x}$ & & & Review & $\begin{array}{l}\text { Human Resource } \\
\text { Management }\end{array}$ \\
\hline Paauwe, 2009 & $\mathrm{x}$ & $\mathrm{x}$ & & & Review & $\begin{array}{l}\text { Journal of } \\
\text { Management Studies }\end{array}$ \\
\hline $\begin{array}{l}\text { Paul and } \\
\text { Anantharaman, } \\
2003\end{array}$ & $\mathrm{x}$ & & & & Quantitative & $\begin{array}{l}\text { International Journal } \\
\text { of Human Resource } \\
\text { Management }\end{array}$ \\
\hline $\begin{array}{l}\text { Posthuma et al., } \\
2013\end{array}$ & $\mathrm{x}$ & $\mathrm{x}$ & & & Review & $\begin{array}{l}\text { Journal of } \\
\text { Management }\end{array}$ \\
\hline Purcell, 2014 & & $\mathrm{x}$ & & & Review & $\begin{array}{l}\text { Human Resource } \\
\text { Management Journal }\end{array}$ \\
\hline $\begin{array}{l}\text { Saridakis et al., } \\
2017\end{array}$ & $\mathrm{x}$ & & & & $\begin{array}{l}\text { Quantitative (meta- } \\
\text { analysis) }\end{array}$ & $\begin{array}{l}\text { Human Resource } \\
\text { Management Review }\end{array}$ \\
\hline $\begin{array}{l}\text { Sheehan et al., } \\
2014\end{array}$ & $\mathrm{x}$ & $\mathrm{x}$ & $\mathrm{x}$ & $\mathrm{x}$ & Qualitative & $\begin{array}{l}\text { Human Resource } \\
\text { Management Journal }\end{array}$ \\
\hline $\begin{array}{l}\text { Shin and Konrad, } \\
2017\end{array}$ & $\mathrm{x}$ & & & & Quantitative & $\begin{array}{l}\text { Journal of } \\
\text { Management }\end{array}$ \\
\hline Singh et al., 2012 & & $\mathrm{x}$ & $\mathrm{x}$ & & Quantitative & $\begin{array}{l}\text { International Journal } \\
\text { of Human Resource } \\
\text { Management }\end{array}$ \\
\hline Sirmon et al, 2011 & & $\mathrm{x}$ & & & Review & $\begin{array}{l}\text { Journal of } \\
\text { Management }\end{array}$ \\
\hline $\begin{array}{l}\text { Van De Voorde et } \\
\text { al., } 2012\end{array}$ & $\mathrm{x}$ & $\mathrm{x}$ & & & Review & $\begin{array}{l}\text { International Journal } \\
\text { of Management } \\
\text { Reviews }\end{array}$ \\
\hline $\begin{array}{l}\text { Van De Voorde } \\
\text { and Beijer, } 2015\end{array}$ & $\mathrm{x}$ & & & & Quantitative & $\begin{array}{l}\text { Human Resource } \\
\text { Management Journal }\end{array}$ \\
\hline $\begin{array}{l}\text { Wall and Wood, } \\
2005\end{array}$ & $\mathrm{x}$ & & & & Review & Human Relations \\
\hline $\begin{array}{l}\text { Welbourne and } \\
\text { Cyr, } 1999\end{array}$ & $\mathrm{x}$ & & $\mathrm{x}$ & & Quantitative & $\begin{array}{l}\text { Academy of } \\
\text { Management Journal }\end{array}$ \\
\hline Wood, 1999 & $\mathrm{x}$ & & & & Review & $\begin{array}{l}\text { International Journal } \\
\text { of Management } \\
\text { Reviews }\end{array}$ \\
\hline Wright et al., 2001 & $\mathrm{x}$ & & & & Review & $\begin{array}{l}\text { Journal of } \\
\text { Management }\end{array}$ \\
\hline $\begin{array}{l}\text { Wright and } \\
\text { McMahan, } 2011\end{array}$ & $\mathrm{x}$ & & & & Review & $\begin{array}{l}\text { Human Resource } \\
\text { Management Journal }\end{array}$ \\
\hline Wright et al., 2014 & $\mathrm{x}$ & & & & Review & $\begin{array}{l}\text { Journal of } \\
\text { Management }\end{array}$ \\
\hline
\end{tabular}

